\title{
The potent sigma receptor ligand PB167, as a potential PET radiotracer for evaluating the mammary sarcoma in mice
}

\author{
Nicola A. Colabufo,* Francesco Berardi, Marialessandra Contino, Mauro Niso, Roberto \\ Perrone, and Vincenzo Tortorella
}

Dipartimento Farmaco-Chimico, Università degli Studi di Bari, via Orabona, 4, 70125, Bari, Italy

E-mail: colabufo@farmchim.uniba.it

\begin{abstract}
$\sigma$ Receptors have been detected in many tissues and are highly expressed in several tumour cell lines from various tissues. In particular, $\sigma_{2}$ receptor subtype is considered to be a potential biomarker for rapid proliferating tumour cells. It was demonstrated that $\sigma_{2}$ receptor agonists and $\sigma_{1}$ receptor antagonists displayed cytotoxic effect and cell proliferation inhibition in several tumour cell lines such as neuroblastoma, glioma and sarcoma. In the last years several $\sigma$ ligands have been radiolabelled for obtaining a potential radiotracer suitable in PET technique and among them $\left[{ }^{11} \mathrm{C}\right]-\mathrm{PB} 28$, our cyclohexylpiperazine derivative, $\left[{ }^{11} \mathrm{C}\right]-\mathrm{SA} 4503$, and $\left[{ }^{11} \mathrm{C}\right]-\mathrm{I}$ derivative. Recently, we synthesized PB167, a potent $\sigma$ receptor ligand that bears between the tetralin nucleus and cyclohexylpiperazine moiety a spacer longer than compound PB28. Moreover, PB167 displayed low $P_{\text {app }}\left(12 \times 10^{-6} \mathrm{~cm} / \mathrm{sec}\right)$ and high clogP (6.19). For this purpose, EMT-6 cells (murine mammary sarcoma) have been selected and subcutaneously implanted in the nape of the neck of mice. In this work we reported both the recognition of $\sigma$ receptors in EMT-6 cells and PB167 $\sigma$ receptor affinity evaluation in EMT-6 cells. The biodistribution of $\left[{ }^{11} \mathrm{C}\right]-\mathrm{PB} 167$ will be reported in the next work in the future.
\end{abstract}

Keywords: Sigma $(\sigma)$ receptor ligands, PET, EMT-6 cells, mammary sarcoma

\section{Introduction}

In the last years sigma $(\sigma)$ receptors have been defined as a distinct class of receptors and classified into $\sigma_{1}$ and $\sigma_{2}$ subtypes. ${ }^{1} \sigma$ Receptors have been detected in many tissues and are highly expressed in several tumour cell lines from various tissues. ${ }^{2,3}$ In particular, $\sigma_{2}$ receptor subtype is considered to be a potential biomarker for rapid proliferating tumour cells. ${ }^{4,5}$

It was demonstrated that $\sigma_{2}$ receptor agonists and $\sigma_{1}$ receptor antagonists displayed cytotoxic effect and cell proliferation inhibition in several tumour cell lines such as neuroblastoma, glioma 
and sarcoma. ${ }^{6-8}$ Furthermore, these agents induced apoptosis with p53- and caspase-independent mechanism in breast cancer cell lines. ${ }^{9}$ The evidenced high level of expression for $\sigma$ receptors in tumour cells and their involvement in cell proliferation and apoptosis encouraged the development of several $\sigma$ ligands in order to obtain a molecular probe for in-vivo diagnostic imaging techniques such as Positron Emission Tomography (PET) and Single Photon Emission Computerized Tomography (SPECT). ${ }^{10-15}$ PET is a sensitive non-invasive imaging technique with the unique capability to measure quantitatively pharmacological, biochemical, and metabolic processes in the human body and in animals in vivo. In addition, a new strategy in tumour therapy could be set up based on the use of $\sigma$ agents. ${ }^{16}$

Recently, several $\sigma$ ligands have been suggested as potential radiotracers for PET study but the results demonstrated that these ligands are unable to recognize $\sigma$ receptors by PET and the possible explanation of these failures involves P-glycoprotein (P-gp) activity. ${ }^{13,17,18}$

The physiological role of P-gp is to protect organs against endogenous and exogenous toxins. P-gp is localized in the brain blood barrier (BBB), in tumour cells, in the adrenal cortex, intestinal mucosal cells, biliary hepatocytes, and the blood capillaries of the testis. ${ }^{19}$

The permeability of the BBB is an important factor determining the bioavailability of CNS drugs. Active transport of these drugs from the brain back into the blood causes a brain accumulation lower than expected because of their lipophilicity. ${ }^{20}$

Moreover, in chemotherapy, the concentration of the agent in tumour tissue should reach a concentration that prohibits the tumor cells proliferation activity. Failure of response to chemotherapy of malignancies can be due to intrinsic or acquired multi drug resistance (MDR). The most exstensively studied mechanism in MDR is P-gp overexpression. ${ }^{21}$

In the last years several $\sigma$ ligands have been radiolabelled for obtaining a potential radiotracer suitable in PET technique and among them $\left[{ }^{11} \mathrm{C}\right]-\mathrm{PB} 28$, our cyclohexylpiperazine derivative, ${ }^{22-25}\left[{ }^{11} \mathrm{C}\right]-\mathrm{SA} 4503,{ }^{26}$ and $\left[{ }^{11} \mathrm{C}\right]-\mathrm{I}$ derivative ${ }^{27}$ (Figure 1).

For each compound is reported the biodistribution of radiotracer in central Nervous System (CNS) and the results displayed for all radiotracers high uptake in CNS even if low specific binding was obtained. A possible explanation of this failure could be that these compounds cross the BBB having high apparent permeability $\left(P_{\text {app }}\right)$ but their high clogP determines also high nonspecific binding in CNS. In particular our compound $\left[{ }^{11} \mathrm{C}\right]-\mathrm{PB} 28$ has $P_{\mathrm{app}}=35 \times 10^{-6} \mathrm{~cm} / \mathrm{sec}$ and $\operatorname{cog} \mathrm{P}=5.19$.

Therefore, these findings led to consider $P_{\text {app }}$ and $\operatorname{cog} \mathrm{P}$ as fundamental determinants to design a radiotracer for PET technique. 
<smiles>COc1cccc2c1CCCC2CCCN1CCN(C2CCCCC2)CC1</smiles>

$\left[{ }^{11} \mathrm{C}\right]-\mathrm{PB} 28^{22-25}$<smiles>COc1ccc(CCN2CCN(CCCc3ccccc3)CC2)cc1OC</smiles>

[11C]-SA4503<smiles>COc1cc2c(cc1OC)CN(CCCCNC(=O)c1ccccc1OC)CC2</smiles>

Figure 1. $\sigma$ radiotracers.

Recently, we synthesized PB167 $7^{25}$ (Figure 2), a potent $\sigma$ receptor ligand that bears between the tetralin nucleus and cyclohexylpiperazine moiety a spacer longer than compound PB28. Moreover, PB167 displayed lower $P_{\text {app }}\left(12 \times 10^{-6} \mathrm{~cm} / \mathrm{sec}\right)$ and higher clogP (6.19) than PB28. 


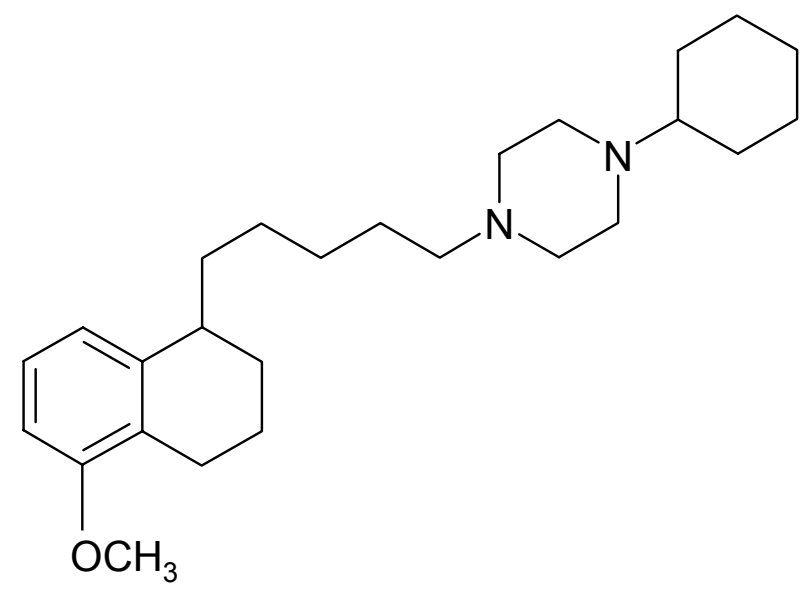

PB167 ${ }^{25}$

Figure 2. PB167 chemical structure.

These preliminary results encouraged us to verify if this compound is suitable as radiotracer to study the mammary sarcoma in mice by PET. For this purpose, EMT-6 cells (murine mammary sarcoma) have been selected and subcutaneously implanted in the nape of the neck of mice. $^{27}$

In this work we reported only the recognition of $\sigma$ receptors in EMT- 6 cells and PB167 $\sigma$ receptor affinity evaluation in EMT-6 cells. The biodistribution of $\left[{ }^{11} \mathrm{C}\right]-\mathrm{PB} 167$ will be reported in the next work in the future.

\section{Results and Discussion}

In order to define the presence of both $\sigma$ receptor subtypes in EMT- 6 cells, saturation binding analysis with radioligands have been performed. As depicted in figure 3 , both $\sigma_{1}$ and $\sigma_{2}$ receptors have been detected in high density $\left(B_{\max }=826 \pm 50 \mathrm{fmol} / \mathrm{mg}\right.$ of protein and $740 \pm 30 \mathrm{fmol} / \mathrm{mg}$ of protein, respectively). These values have been determined with $(+)-\left[{ }^{3} \mathrm{H}\right]$-pentazocine $\left(K_{\mathrm{d}}=4.17\right.$ $\pm 0.30 \mathrm{nM})$ for $\sigma_{1}$ receptor and $\left[{ }^{3} \mathrm{H}\right]-\mathrm{DTG}\left(K_{\mathrm{d}}=6.41 \pm 0.50 \mathrm{nM}\right)$ for $\sigma_{2}$ subtype. 

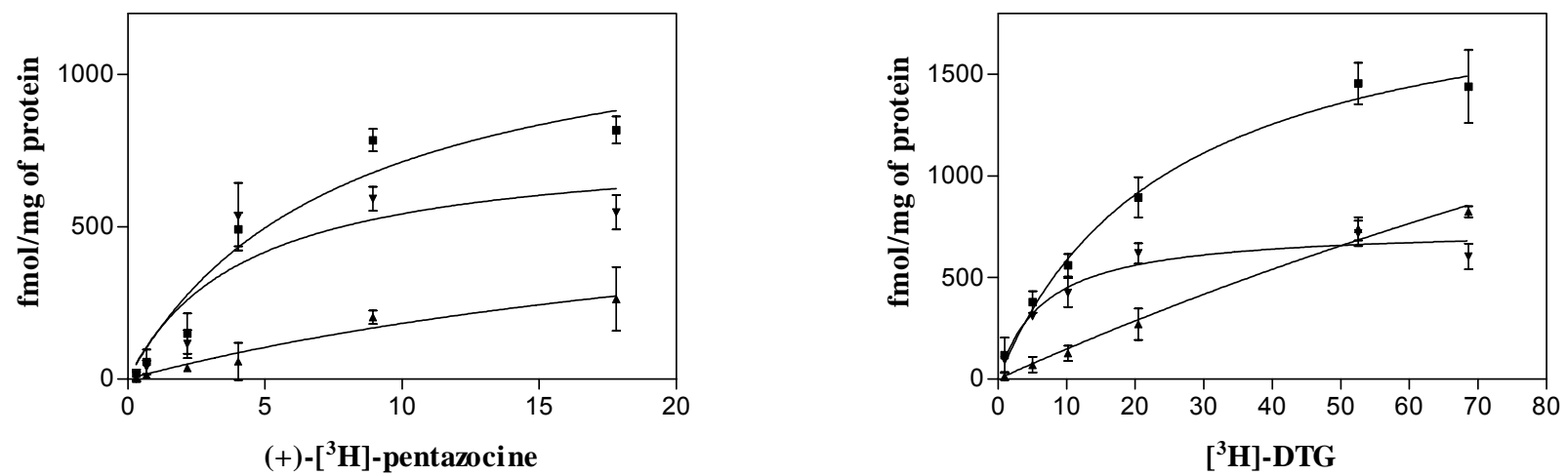

- Total binding, $\boldsymbol{\nabla}$ Specific binding, $\boldsymbol{\Delta}$ Nonspecific binding

Figure 3. Saturation binding analysis in EMT-6 cells with radioligand, $(+)-\left[{ }^{3} \mathrm{H}\right]$-pentazocine and $\left[{ }^{3} \mathrm{H}\right]$-DTG for detecting $\sigma_{1}$ and $\sigma_{2}$ receptors, respectively.

Moreover, it was determined in EMT-6 cells for compound PB167 the recptor affinity towards both $\sigma$ subtypes, the antiproliferative and cytotoxic effects. The results listed in table 1 displayed that PB167 has high $\sigma_{2}$ receptor affinity but only a moderate $\sigma_{1}$ receptor affinity $(0.30$ $\pm 0.10 \mathrm{nM}$ and $16.5 \pm 0.40 \mathrm{nM}$, respectively). Moreover, compound PB167 showed both antiproliferative and cytotoxic effects in EMT-6 cells $\left(\mathrm{EC}_{50}=15.9 \pm 2.6 \mu \mathrm{M}\right.$, and $56.5 \pm 2.8 \mu \mathrm{M}$, respectively).

Table 1. PB167 Biological evaluation in EMT-6 cell line

\begin{tabular}{ccccc}
\hline$\sigma_{1}$ & $\sigma_{2}$ & & Antiproliferative effect & Cytotoxic effect \\
\cline { 1 - 1 }$K_{\mathrm{i}} \pm \mathrm{SEM}, \mathrm{nM}$ & & \multicolumn{2}{c}{$\mathrm{EC}_{50} \pm \mathrm{SEM}, \mu \mathrm{M}$} \\
$0.30 \pm 0.10$ & $16.5 \pm 0.40$ & & $15.9 \pm 2.6$ & $56.5 \pm 2.6$ \\
\hline
\end{tabular}

Preliminary $\left[{ }^{11} \mathrm{C}\right]-\mathrm{PB} 167$ biodistribution results (unpublished) demonstrated that the uptake of this compound in CNS is low and this found is consistent with low $P_{\text {app }}$ of compound PB167. By contrast, the uptake in tumour tissue is the same than in normal muscle tissue. A possible explanation of this disappointing result could be that tumour cell overexpressed P-glycoprotein so that only a low concentration of radiotracer is visualized into the tumour cells. The antiproliferative and cytotoxic effects of PB167 confirmed that $\sigma$ ligands are potential antineoplastic drugs when these receptors are overexpressed in tumour cells. In conclusion, these results suggested PB167 as a potential radiotracer for recognizing peripheral tumour cells overexpressing $\sigma$ receptors even if the role of P-gp overexpression in tumour cells will be better investigated. Moreover, the permeability evaluation $\left(P_{\text {app }}\right)$ is the most important parameter to predict the possible distribution in CNS. 


\section{References}

1. Hellewell, S. B.; Bowen, W. D. Brain Res. 1990, 527, 244.

2. Vilner, B. J.; John, C. S.; Bowen, W. D. Cancer Res. 1995, 55, 408.

3. John C. S.; Vilner, B. J.; Schwartz, A. M.; Bowen, W. D. J. Nucl. Med. 1996, 37, 267 P.

4. Mach, R. H.; Smith, C. R.; Al-Nabusi, I.; Whirrett, B. R.; Childers, S. R.; Wheeler, K. T. Cancer Res. 1997, 57, 156.

5. Wheeler, K. T.; Wang, L. M.; Wallen, C. A.; Childers, S. R.; Cline. J. M.; Keng, P. C.; Mach, R. H. Br. J. Canc. 2000, 82, 1223.

6. Vilner, B. J.; Bowen, W. D. J. Pharmacol. Exp. Ther. 2000, 292, 900.

7. Colabufo, N. A.; Berardi, F.; Contino, M.; Niso, M.; Abate, C.; Perrone, R.; Tortorella, V. Naunyn Schmiedeberg's Arch. Pharmacol. 2004, 370, 106.

8. Spruce, B. A.; Campbell, L. A.; McTavish, N.; Cooper, M. A.; Appleyard, M. V. L.; O’Neill, M.; Howie, J.; Samson, J.; Watt, S.; Murray, K.; McLean, D.; Leslie, N. R.; Safrany, S. T.; Ferguson, M. J.; Peters, J. A.; Prescott, A. R.; Box, G.; Hayes, A.; Nutley, B.; Raynaud, F.; Downes, C. P.; Lambert, J. J.; Thompson, A. M.; Eccles, S. Cancer Res. 2004, $54,4875$.

9. Crawford, K. W., Bowen, W. D. Cancer Res. 2002, 62, 313.

10. John, C. S.; Gulden, M. E.; Li, J. H.; Bowen, W. D.; McAfee, J. G.; Thakur, M. L. Nucl. Med. Biol. 1998, 25, 189.

11. Mach, R. H.; Huang, Y.; Buchheimer, N.; Kuhner, R.; Wu, L.; Morton, T. E.; Wang, L. M.; Ehrenkaufer, R. L.; Wheeler, K. T. Nucl. Med. Biol. 2001, 28, 451.

12. Elsinga, P. H., Kawamura, K., Kobayashi, T., Tsukada, H., Senda, M., Vaalburg, W., Ishiwata, K. Synapse 2002, 43, 259.

13. Kawamura, K.; Kobayashi, T.; Matsuno, K.; Ishiwata, K. Synapse 2003, 48, 80.

14. Kawamura, K.; Elsinga, P. H.; Kobayashi, T.; Ishii, S.; Wang, W. F.; Vaalburg, W.; Ishiwata, K. Nucl Med. Biol. 2003, 30, 273.

15. Van Waarde, A.; Buursma, A. R.; Hospers, G. A.; Kawamura, K.; Kobayashi, T.; Ishii, K.; Oda, K.; Ishiwata, K.; Vaalburg, W.; Elsinga, P. H. J. Nucl. Med. 2004, 45, 1939.

16. Caveliers, V.; Everaert, H.; Lahoutte, T.; Dierickx, L. O.; John, C. S.; Bossuyt, A. Eur. J. Nucl. Med. 2001, 28, 133.

17. Mach, R. H.; Gage, H. D.; Burchheimer, N.; Huang, Y.; Kuhner, R.; Wu, L.; Morton, T. E.; Ehrenkaufer, R. L. Synapse 2005, 58, 267.

18. James, M. L.; Fulton, R. R.; Henderson, D. J.; Eberl, S.; Meikle, S. R.; Thomson, S.; Allan, R. D.; Dolle, R. D.; Dolle, F.; Fulham, M. J.; Kassiou, M. Bioorg. Med. Chem. 2005, 15, 6188 .

19. Leslie, E. M.; Deeley, R. G.; Cole, S. P. C. Toxicol. Appl. Pharmacol. 2005, 204, 216.

20. Sasongko, L.; Link, J.; Muzi, M.; Mankoff, D.; Yang, X.; Collier, S.; Shoner S.; Unadkat J. Clin. Pharmacol. Ther. 2005, 77, 503. 
21. Vaalburg, W.; Hendrikse, N. H.; Elsinga, P. H.; Bart, J.; van Waarde, A. Toxicol. Appl. Pharmacol. 2005, 207, 257.

22. Kassiou, M.; Dannals, R. F.; Liu, X.; Wong, D. F.; Ravert, H. T.; Scheffel, U. A. Bioorg. Med. Chem. 2005, 13, 3623.

23. Berardi, F.; Colabufo, N. A.; Giudice, G.; Perrone, R.; Tortorella V.; Govoni S.; Lucchi, L.; J. Med. Chem. 1996, 39, 176.

24. Perrone, R.; Berardi, F.; Colabufo, N. A.; Leopoldo, M.; Abate, C.; Tortorella, V. Med. Chem. Res. 2000, 10, 201.

25. Berardi, F.; Ferorelli, S.; Abate, C.; Colabufo, N. A.; Contino, M.; Perrone, R.; Tortorella, V. J. Med. Chem. 2004, 47, 2308.

26. Kawamura, K.; Kobayashi, T.; Matsuno, K.; Ishiwata, K. Synapse, 2003, 48, 80.

27. Tu, Z.; Dence, C. S.; Ponde, D. E., Jones, L.; Wheeler, K. T.; Welch, M. J.; Mach, R. H. Nucl. Med. Biol. 2005, 32, 423. 